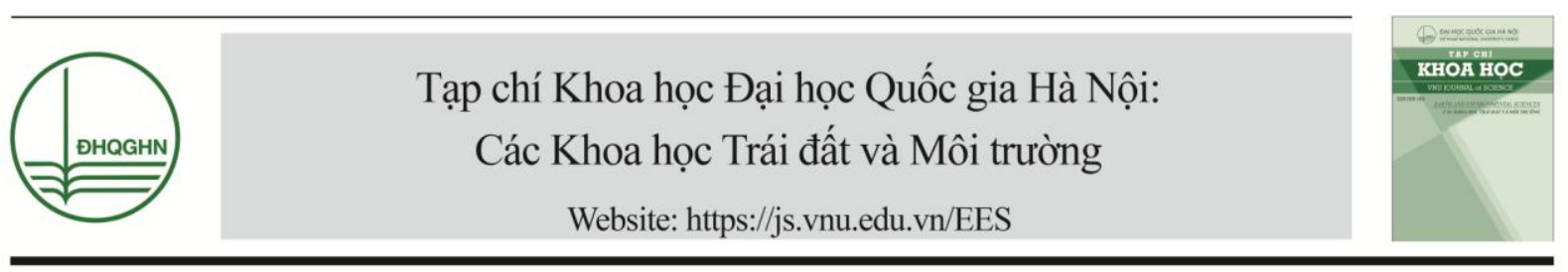

\title{
Tiến hóa các hệ thống cồn cát và vai trò của chúng đối với lịch sử bồi tụ châu thổ sông Mekong trong holocen muộn
}

\author{
Nguyễn Thị Huyền Trang*, Trần Nghi, Đinh Xuân Thành, \\ Trần Thị Thanh Nhàn, Nguyễn Thị Tuyến \\ Trường Đại học Khoa học Tự Nhiên, ĐHQGHN, 334 Nguyến Trãi, Hà Nội, Việt Nam \\ Nhận ngày 17 tháng 4 năm 2018 \\ Chỉnh sửa ngày 07 tháng 5 năm 2018; Chấp nhận đăng ngày 09 tháng 5 năm 2018
}

\begin{abstract}
Tóm tắt: Hệ thống cồn cát trên đồng bằng sông Mekong đóng vai trò là các mốc đánh dấu quá trình phát triển của châu thổ về phía biển từ hơn 5.000 năm trở lại đây. Các thế hệ giồng cát chính là dấu ấn các thế hệ đường bờ cổ trong quá trình châu thổ bồi tụ. Nghiên cứu này trình bày một số kết quả nghiên cứu mới về lịch sử tiến hóa hệ thống cồn cát trên đồng bằng châu thổ sông Mekong dựa trên phân tích tổng hợp các số liệu địa chất, địa mạo, tân kiến tạo và định tuổi tuyệt đối bằng phương pháp huỳnh quang kích thích (OSL) và ${ }^{14} \mathrm{C}$. Những kết quả mới đã ghi nhận năm thế hệ cồn cát với tuổi tương ứng 5.000 năm, 2.500 năm, 1.000 năm, 500 năm và thế hệ cồn cát đang hình thành tại đường bờ hiện đại. Càng về phía biển tuổi các cồn cát càng trẻ. Hiện nay, tại khu vực tiền châu thổ đang hình thành một hệ thống cồn ngầm phân bố về phía nam và đông nam của các cửa sông. Các tính toán dựa trên tuổi tuyệt đối các thế hệ cồn cát cổ cho phép dự đoán trong 200 năm tới các cồn cát ngầm này sẽ nổi cao và được nối với đất liền ở độ cao $5 \mathrm{~m}$ như các cồn cát hiện tại. Lúc đó, châu thổ sông Mekong lại bước sang giai đoạn bồi tụ mạnh mẽ và tiền châu thổ hiện tại sẽ biến thành đồng bằng châu thổ thấp.
\end{abstract}

Tù khóa: Giồng cát ${ }^{1}$, cồn cát ${ }^{2}$, châu thổ sông Mekong, đường bờ cổ.

\section{Mở đầu}

Đồng bằng châu thổ sông Mekong đặc trưng bởi hệ thống giồng cát hình cánh cung song song với bờ biển (Hình 1). Tuổi của các giồng cát đã được Toru Tamura, Yoshi Saito,

\footnotetext{
*Tác giả liên hệ. ĐT.: 84-987878409.

Email: nguyentrang181@gmail.com

https://doi.org/10.25073/2588-1140/vnunst.4247

1 Thuật ngữ "giồng cát" trong bài báo này dùng để chỉ những cồn cát cửa sông cổ hiện nằm trên đất liền.
}

(2012) xác định bằng phương pháp nhiệt huỳnh quang kích thích [1], [2]. Tuy nhiên với khối lượng tài liệu đồ sộ thu được như vậy nhưng vẫn chưa được khai thác một cách triệt để vào mục tiêu nghiên cứu trầm tích luận nhằm làm sáng tỏ sự hình thành và phát triển các cồn cát, sự tăng trưởng các đường bờ cổ và chu kỳ trầm tích trong mối quan hệ với sự thay đổi mực nước biển. Nội dung bài báo sẽ trình bày chi tiết đặc điểm các cồn cát và cồn ngầm châu thổ sông Mekong giúp thiết lập lịch sử tiến hóa hệ thống cồn cát từ đó dự báo xu thế biến đổi châu 
thổ sông Mekong trong tương lai nhằm đề xuất giải pháp bảo vệ bờ biển. Sự tồn tại các giồng cát chứng tỏ ở đó từng là bờ biển, càng gần biển thì tuổi các giồng cát càng trẻ. Các đặc điểm địa hình, địa mạo và đặc điểm trầm tích của hệ thống cồn cát phản ánh chế độ tương tác động lực sông, biển và có thể một phần tác động của gió. Kết quả động lực sông thắng thế tạo nên các cồn cát dần tiến ra biển. Hệ thống cồn cát vốn là các cồn ngầm dưới đáy biển, do quá trình tương tác của sóng biển và dòng chảy ven bờ, tại đới sóng đổ tốc độ dòng ngang bằng 0 , động lực sóng đạt cực đại. Tại đó, trầm tích cát được tích tụ tạo nên một cồn cát ngầm trước cửa sông. Vào mùa nước dâng do bão, cồn cát ngầm được tôn cao ngang mực nước biển. Khi bão tan, mực nước hạ thấp xuống mức bình thường cồn cát tạo thành cồn nổi.

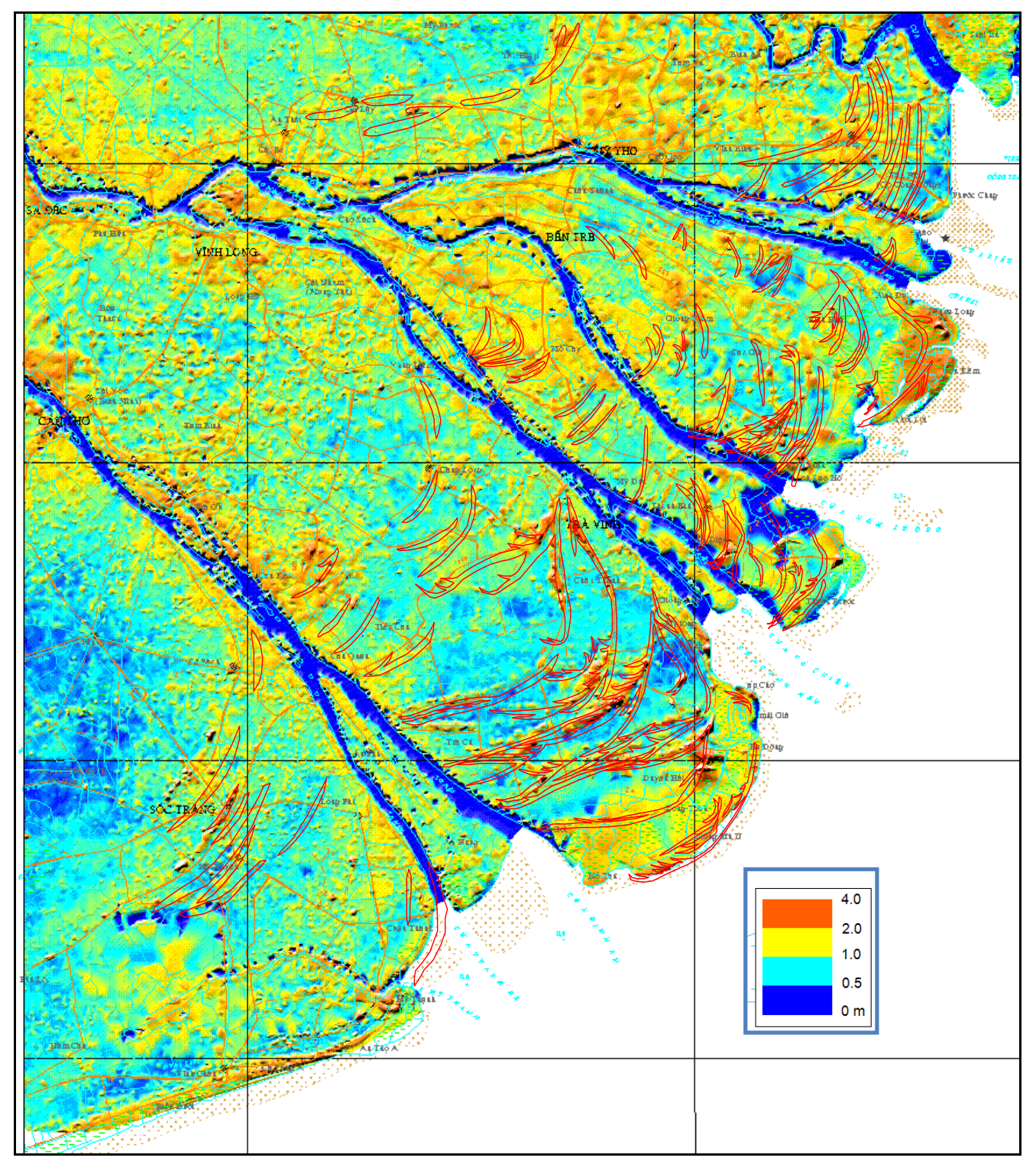

Hình 1. Bản đồ địa hình (3D) đồng bằng châu thổ sông Mekong và vị trí các giồng cát. 


\section{Cơ sở tài liệu và phương pháp nghiên cứu}

\subsection{Co sở tài liệu}

Các số liệu nghiên cứu chủ yếu dựa trên tài liệu, số liệu thuộc đề tài $\mathrm{KC} 09.13 / 11$-15 và các công bố trong và ngoài nước khác. Các số liệu này bao gồm số liệu tuổi tuyệt đối (tuổi huỳnh quang kích thích - OSL, tuổi ${ }^{14} \mathrm{C}$ ), tài liệu phân tích địa tầng dựa trên mô tả mẫu lõi khoan và trầm tích tầng mặt (Bảng 1 ). Ngoài ra các dũ liệu ảnh Google Earth, ảnh vệ tinh và bản đồ độ đâu đáy biển tỷ lệ 1:50.000 được sử dụng để xác định vị trí, hình dạng các hệ thống cồn cát trong khu vực.

\subsection{Phưong pháp nghiên cưu}

1/ Phương pháp phân tích ảnh vệ tinh Landsat và Spot. Các ảnh vệ tinh được sử dụng trong nghiên cứu này là ảnh đa phổ có độ phân giải đáp ứng được các yêu cầu cho nghiên cứu địa mạo và địa chất khu vực tỉ lệ nhỏ. Các hệ cồn cát vị trí đường bờ và ranh giới đất/nước được xác định dựa trên sự tương phản về phổ màu có đối sánh với các thực thể ngoài thực địa.

2/ Các phương pháp nghiên cứu trầm tích luận nhằm xác định thành phần vật chất, nguồn gốc, môi trường động lực thành tạo các thế hệ cồn cát, bao gồm: phân tích độ hạt trầm tích bở rời (xác định hàm lượng: sạn, cát, bột, sét, $\mathrm{Md}$, So, Sk), phân tích lát mỏng thạch học (xác định thành phần khoáng vật, $\mathrm{Md}$, So, Sk, hàm lượng thạch anh $(\mathrm{Q})$, hàm lượng xi măng $(\mathrm{Li})$, hệ số mài tròn $(\mathrm{Ro})$, độ trưởng thành $(\mathrm{Mt}) .$. ) (bảng 1) và phân tích tướng trầm tích.

3/ Phương pháp xác định tuổi trầm tích. Tuổi hình thành các cồn cát được xác định nhờ phương pháp xác định tuổi huỳnh quang kích thích OSL là thời gian cuối cùng các thành tạo này được xuất lộ; trong khi đó phân tích đồng vị ${ }^{14} \mathrm{C}$ từ di tích thực vật sống tại chỗ và vỏ sò nguyên dạng sẽ cho phép xác định được tuổi lắng đọng của các trầm tích chứa các di tích sinh vật đó (trong điều kiện không có quá trình tái trầm tích xảy ra).

Bảng 1. Các số liệu phân tích mẫu

\begin{tabular}{lllllll}
\hline $\begin{array}{l}\text { Đối tượng } \\
\text { lấy mẫu }\end{array}$ & $\begin{array}{l}\text { Độ sâu } \\
(\mathrm{m})\end{array}$ & $\begin{array}{l}\text { Phân tích độ hạt } \\
\text { (số mẫu) }\end{array}$ & $\begin{array}{l}\text { *Tuổi C } \mathrm{C}^{14} \\
\text { (ngăn năm) }\end{array}$ & $\begin{array}{l}\text { **Tuồi OSL } \\
\text { (ngàn năm/số } \\
\text { mẫu) }\end{array}$ & $\begin{array}{l}\text { Phân tích lát } \\
\text { mỏng thạch } \\
\text { học }\end{array}$ & $\begin{array}{l}\text { Eh, } \mathrm{pH}, \\
\mathrm{Kt}\end{array}$ \\
\hline $\begin{array}{l}\text { Giồng cát } \\
\begin{array}{l}\text { Đồng bằng } \\
\text { châuu thố }\end{array}\end{array}$ & $0-20$ & 215 & 10 & $5 / 47$ & 120 & - \\
$\begin{array}{l}\text { Mẫu lõi } \\
\text { khoan }\end{array}$ & $0-15$ & 150 & 15 & - & 50 & 30 \\
\hline
\end{tabular}

Chú thích: Mẫu phân tích độ hạt và lát mỏng thạch học, Eh, pH, Kt sử dụng kết quả đề tài KC09-13/11-15 [3]; Mẫu xác định tuổi $\mathrm{C}^{14}$ sử dụng kết quả của Nguyễn Địch Dỹ, 2010 [4]; Mẫu OSL sử dụng của Tamura, Yoshi Saito, 2012 [1], [2]

\section{Kết quả và thảo luận}

\section{1. Đồng bằng châu thổ}

Từ những số liệu phân tích thu được, nghiên cứu đã xác định các trầm tích của đồng bằng châu thổ sông Mekong bao gồm hai đơn vị tướng: (1) Tướng giồng cát và (2) Tướng bột sét bãi bồi châu thổ. Chi tiết về các tướng được mô tả cụ thể như sau:

\section{Tướng giồng cát}

Đồng bằng châu thổ sông Mekong có địa hình nghiêng thoải về phía biển trên đó nổi lền các giồng cát, chạy theo hình vòng cung và song song với bờ biển (Hình 1 ). Càng về phía biển, các giồng này càng cao và càng rộng. Giồng cát được phân bố theo từng thế hệ, mỗi thế hệ đánh dấu một đường bờ cổ. Khoảng cách giữa 2 giồng cát $1,9-4,9 \mathrm{~km}$, trung bình $2,4 \mathrm{~km}$. 
Do sự chia cắt bởi các giồng và hệ thống trục lộ, kênh rạch chằng chịt nên địa hình khá phức tạp. Các giồng cát có hình dạng đơn hoặc phân nhánh, dài một vài $\mathrm{km}$ đến $28 \mathrm{~km}$, rộng thường gặp 0,4-1 km, cao phổ biến $1,5-3,5 \mathrm{~m}$, cong lồi về phía Đông Nam. Các giồng này thường được cấu tạo bởi cát xốp, dày một vài mét đến $15 \mathrm{~m}$. Giồng cát phát triển với mật độ cao hơn $(1,9-2,1 \mathrm{~km} /$ giồng) ở các vùng Ba Lai-Định An, thấp hơn vùng Cửa Đại-Ba Lai và thấp nhất ở vùng Tranh Đề-Mỹ Thạnh.

Cấu trúc của một giồng cát được thể hiện theo hai phương khác nhau: (1) Phương vuông góc với trục dài giồng cát có 3 đới (Hình 2): đới trung tâm (1), đới trong (2) và đới ngoài (3).

- Đới trung tâm (1) gồm tướng cát hạt nhỏ đồng nhất, chọn lọc và mài tròn tốt

- Đới trong (2) và đới ngoài (3)
Đới trong và đới ngoài có địa hình thấp nghiêng thoải về phía đồng bằng bãi bồi. Chúng gồm 2 tướng: tướng sét màu xám xanh đen chứa than bùn đầm lầy ven biển phủ trên tướng cát bột chọn lọc trung bình của 2 rìa giồng cát. Đới trung tâm của giồng cát (1) gồm tướng cát hạt nhỏ có độ mài tròn và chọn lọc tốt $(\mathrm{So}=$ 1,2-1,5, Ro = 0,6-0,8) (Hình 3a, 3b, 3c, 3d). Thành phần cấp hạt của đới trong cát là chủ yếu (60-90\%), còn lại là bột sét và vụn vỏ sò vì vậy đã tạo nên màu vàng nâu đặc trưng cho môi trường oxi hóa. Kích thước hạt trung bình $(\mathrm{Md})$ dao động từ 0,1 đến $0,21 \mathrm{~mm}$. Trầm tích luôn luôn có độ chọn lọc tốt $(\mathrm{So} \leq 1,5)$ và mài tròn từ trung bình đến tốt $(\mathrm{Ro}>0,5)$. Thành phần khoáng vật chủ yếu là thạch anh, chiếm từ 60 $70 \%$, felspat $20-25 \%$, mảnh đá khoảng 10-15\% (Hình $3 \mathrm{c}, 3 \mathrm{~d})$. Trầm tích giồng cát thường nghèo di tích thực vật và vi cổ sinh.

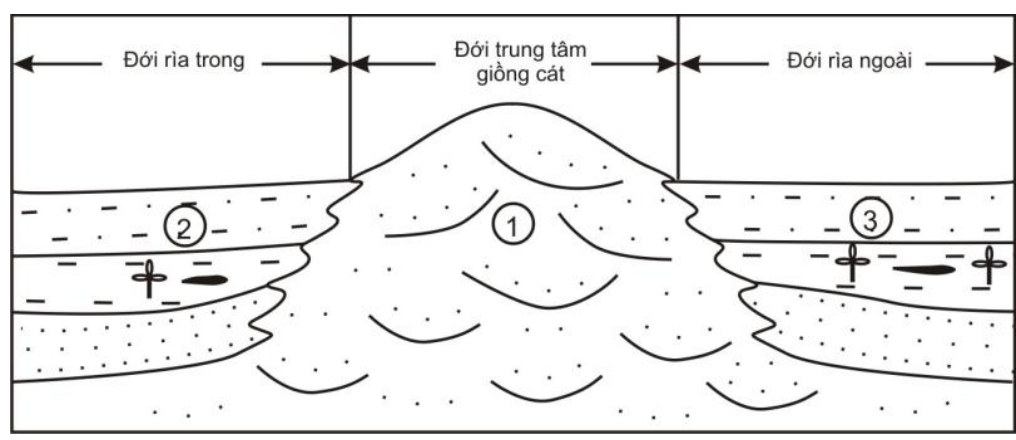

Hình 2. Cấu trúc của giồng cát theo phương nằm ngang và phương thẳng đứng.

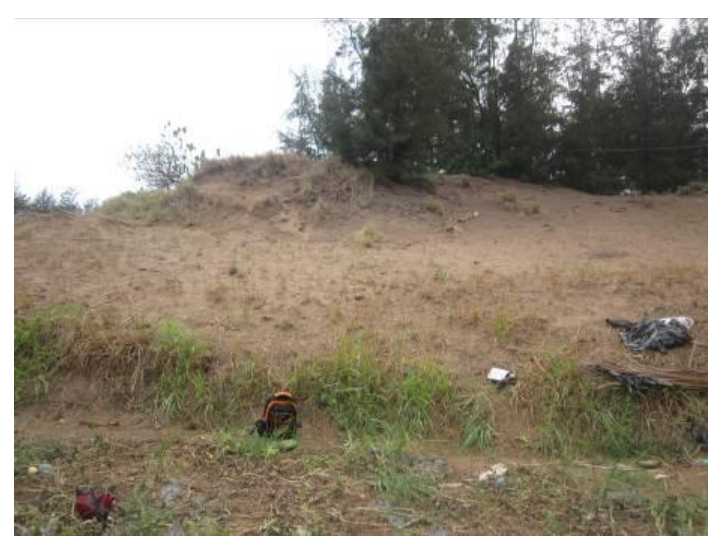

Hình 3a. Giồng cát đồng bằng châu thổ Trà Vinh [3].

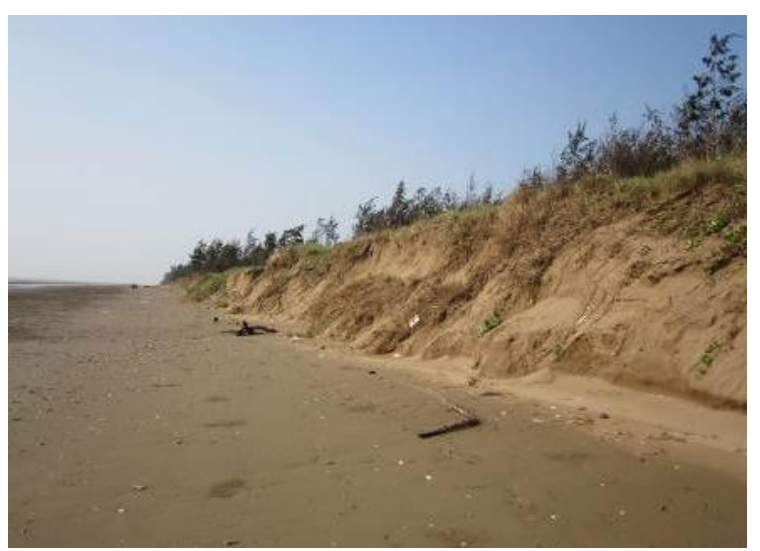

Hình 3b. Giồng cát hiện đại ở Ba Động - Trà Vinh [3]. 


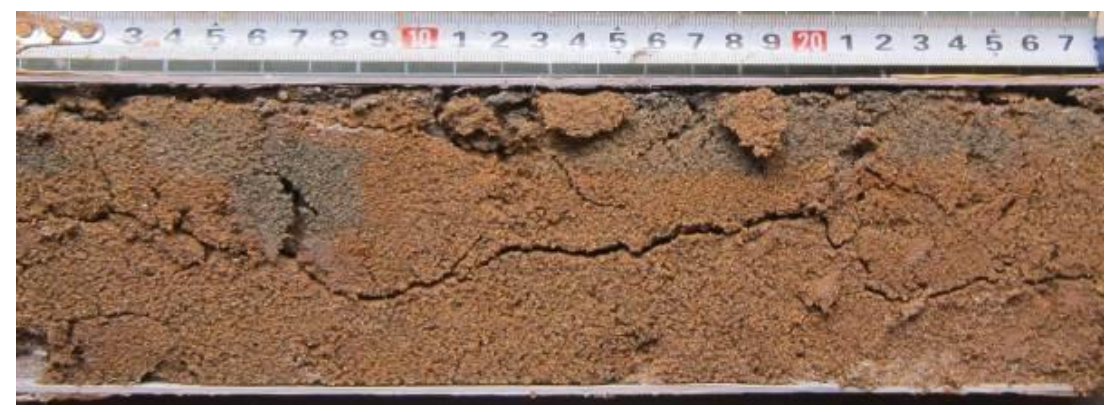

Hình 3c. Trầm tích cồn chắn cửa sông (giồng cát) gặp trong lỗ khoan nông vùng Duyên Hải, Trà Vinh.
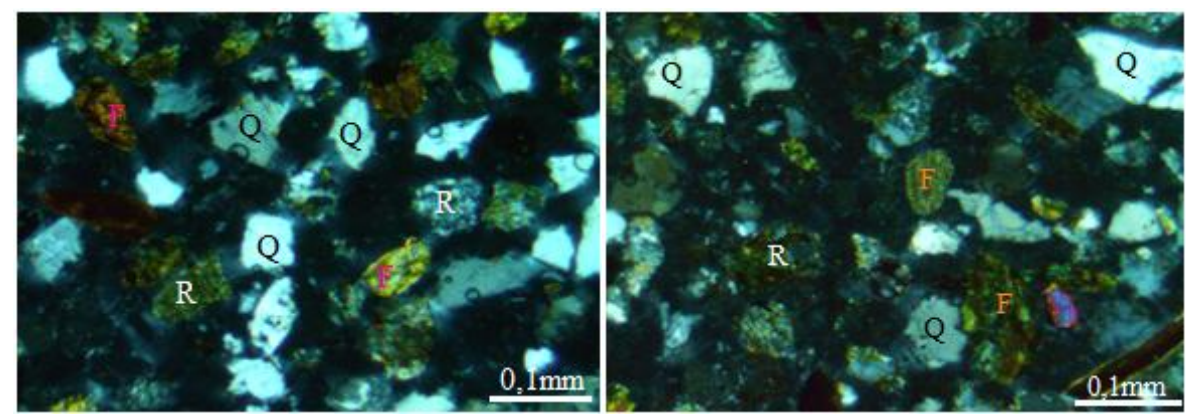

Hình 3d. Ảnh lát mỏng trầm tích cát giồng cát mẫu $\mathrm{GC12}$ và $\mathrm{GC19}$ vùng Duyên Hải, Trà Vinh $\left(\mathrm{N}^{+}, 10 \mathrm{x}\right)$.

\section{Tướng bột sét bãi bồi châu thổ}

Tướng bột sét bãi bồi châu thổ có địa hình bằng phẳng nghiêng thoải về phía biển. Trên đồng bằng châu thổ sông Mekong nhóm tướng này chiếm một diện tích rộng lớn và đóng vai trò quyết định. Chúng được thành tạo trong những thời kỳ ngập lụt do nước biển dâng khi bão xuất hiện và nước sông dâng cao do mưa lũ dài ngày. Trầm tích bột sét bãi bồi châu thổ thường có màu nâu và màu xám đen, chọn lọc kém. Trên diện tích bằng phẳng này phát triển nhiều hệ thống kênh rạch chằng chịt [5]. Đây là dấu tích của các lạch triều ven biển chúng nối tiếp nhau liên tục từ đất liền ra đến bờ biển hiện đại.

\subsection{Châu thổ ngập nuớc hiện đại}

Châu thổ ngập nước bao gồm 3 nhóm tướng cơ bản: (1) nhóm tướng cồn cát cửa sông, (2) nhóm tướng bùn cát tiền châu thổ và (3) nhóm tướng bùn sườn châu thổ. Hai nhóm tướng đầu (1) và (2) phân bố trên địa hình tiền châu thổ (độ sâu từ $0-7 \mathrm{~m}$ nước, cách bờ từ $15-25 \mathrm{~km}$ ) bằng phẳng, nghiêng thoải (Vùng $\mathrm{I}$, Hình 4a).
Nhóm tướng (3) phân bố trên địa hình sườn châu thổ (độ sâu 7-23m nước, rộng khoảng $5 \mathrm{~km}$ ) với đặc trưng độ dốc lớn, hẹp (Vùng II, Hình 4a).

\section{Cồn cát cửa sông hiện đại}

Cồn cát cửa sông hiện đại có hai dạng: cồn cát ngầm và cồn cát nổi (Hình $5 \mathrm{a}, 5 \mathrm{~b})$. Những cồn cát ngầm là những "mầm" cát của cồn cát chắn cửa sông, phân bố thành từng chuỗi nằm trên trường cát tiền châu thổ dưới tác dụng của động lực sóng và dòng chảy ven bờ. Các cồn cát dạng này thường phân bố về phía nam và đông nam của các cửa sông (Hình $5 \mathrm{a}$ ). Trong vùng nghiên cứu phát hiện được một số dạng cồn chắn sau:

- Dạng cồn ngầm đang chìm dưới mặt nước cách khá xa cửa sông được phát hiện trên các băng đo sâu và bản đồ địa hình đáy biển tỷ lệ 1:50.000 [6]. Dạng này hiện phân bố trước các cửa sông Cửa Đại (Hình 6a), Hàm Luông và Mỹ Thạnh (Hình 6b). Các cồn ngầm này kéo dài từ $1-2 \mathrm{~km}$ theo hướng nam và cách bờ biển khoảng 5-6km. 
- Dạng cồn cát cửa sông nổi mập mở trên mặt biển được phát hiện trên ảnh vệ tinh và bản đồ địa hình đáy biển gặp ở phía nam cửa Cung Hầu (Hình $4 \mathrm{a}, 6 \mathrm{c})$. Cồn cát này kéo dài khoảng $5 \mathrm{~m}$ theo hướng bắc nam, đỉnh cồn cách bờ biển khoảng $4 \mathrm{~km}$.
- Dạng cồn cát đã nổi tương đối trên mực nước biển trung bình, hiện đã gần nối liền với bờ biển hiện đại, chỉ cách với đất liền bởi một lạch triều nhỏ. Cồn cát dạng này phát hiện ở phía nam Cửa Tiểu (Hình $4 \mathrm{~b}$ ) với chiều dài khoảng $3,5 \mathrm{~km}$ và rộng $1,6 \mathrm{~km}$.

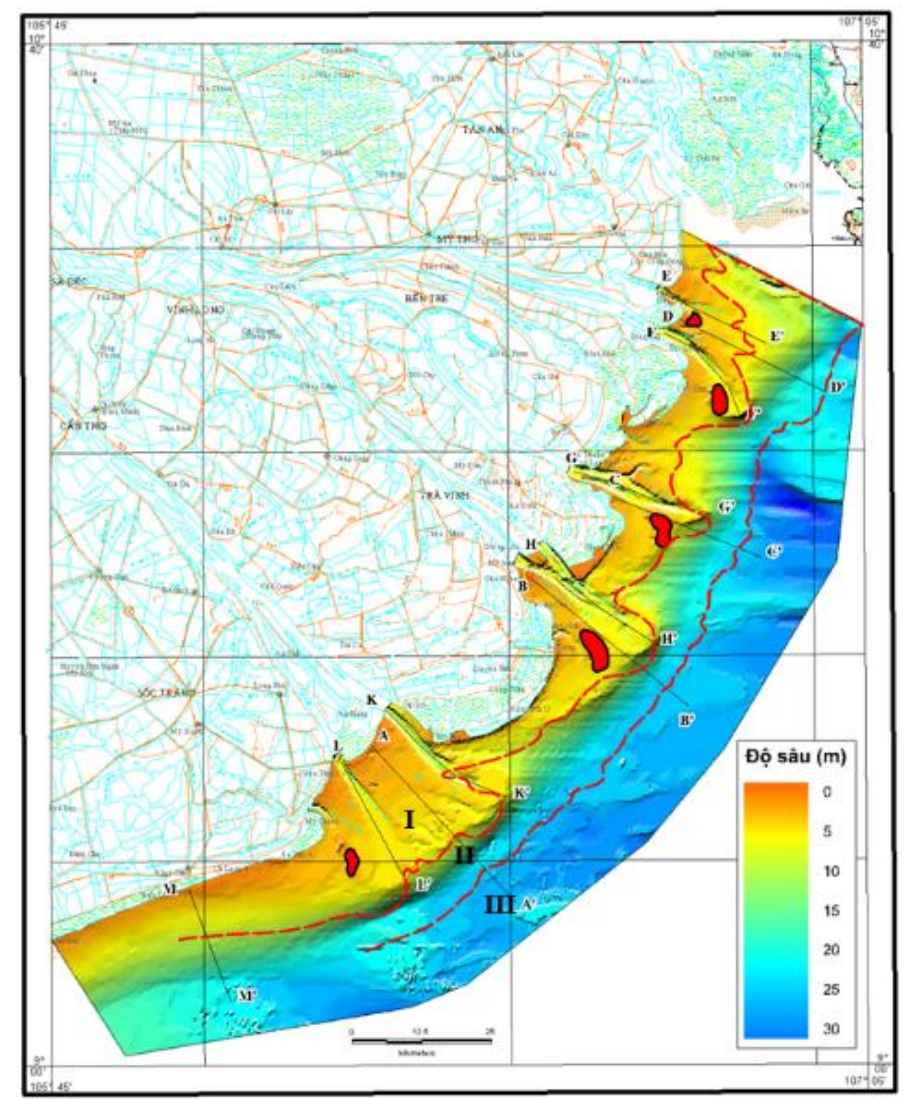

Hình 4a. Sơ đồ mô hình số độ cao (3D) vùng châu thổ ngầm sông Mekong, vị trí hệ thống cồn ngầm và các tuyến vẽ mặt cắt địa hình (thu nhỏ từ tỷ lệ 1:50.000).

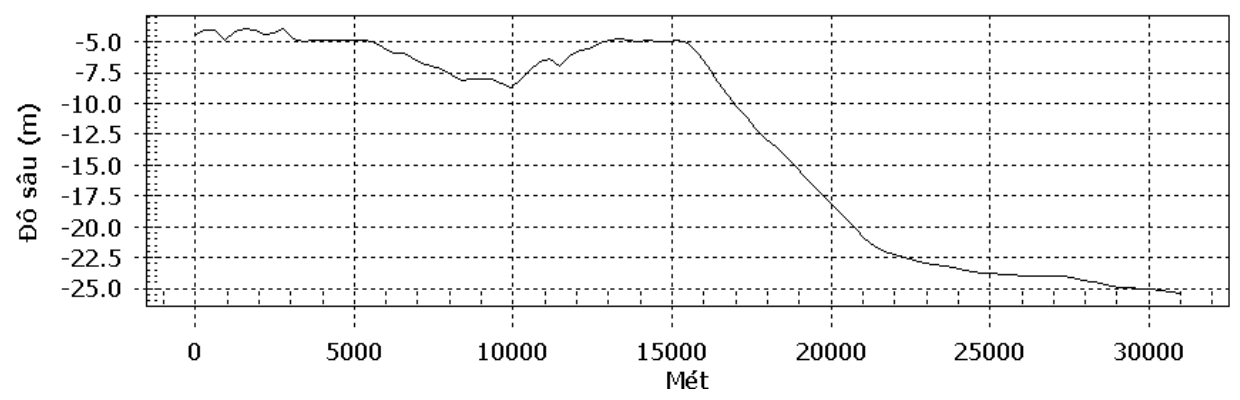

Hình 4b. Mặt cắt địa hình đáy biển vùng cửa Hàm Luông theo đường $\mathrm{CC}^{\prime}$ ', quan sát rõ địa hình nổi cao của cồn ngầm trước cửa Hàm Luông. 


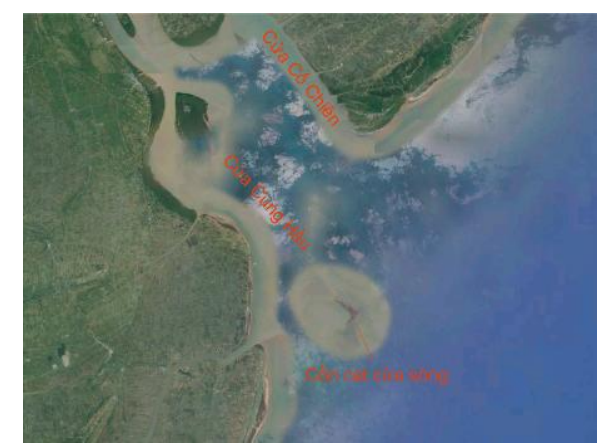

Hình $5 \mathrm{a}$. Cồn cát ngầm cửa sông gần nổi cao phía đông nam Cung Hầu (Google Earth).

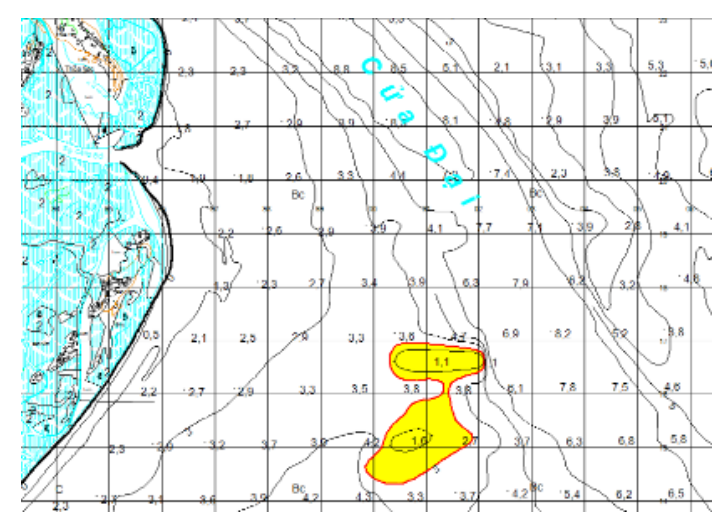

Hình 6a. Cồn cát ngầm cửa sông phía đông nam Cửa Đại [6].

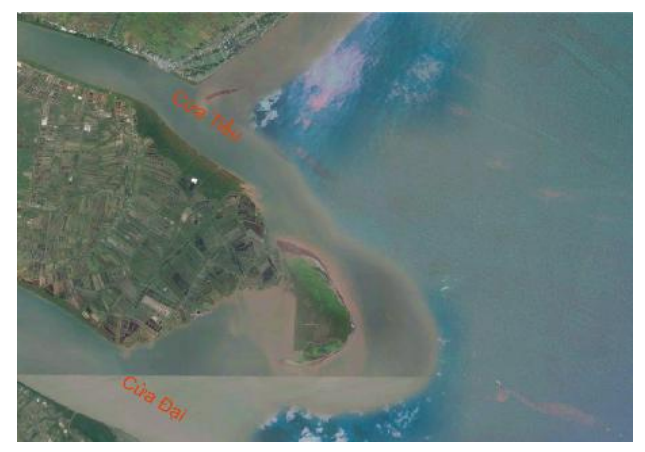

Hình $5 b$. Cồn cát ngầm cửa sông nay được nổi cao phía nam Cửa Tiểu (Google Earth).

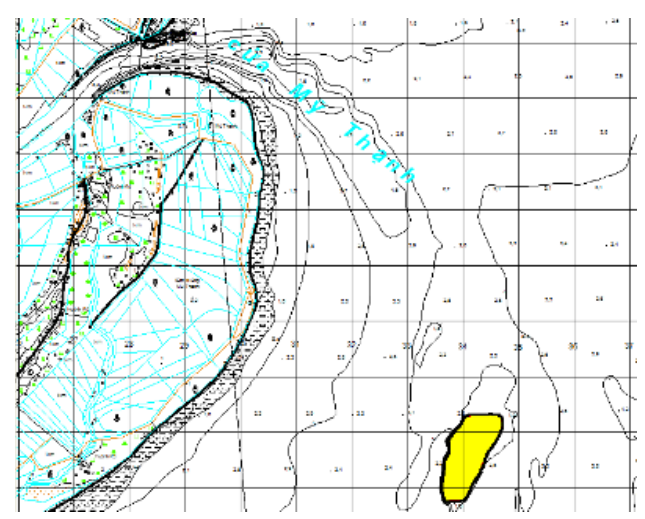

Hình 6 b. Cồn cát ngầm cửa sông phía đông nam cửa Mỹ Thạnh [6].

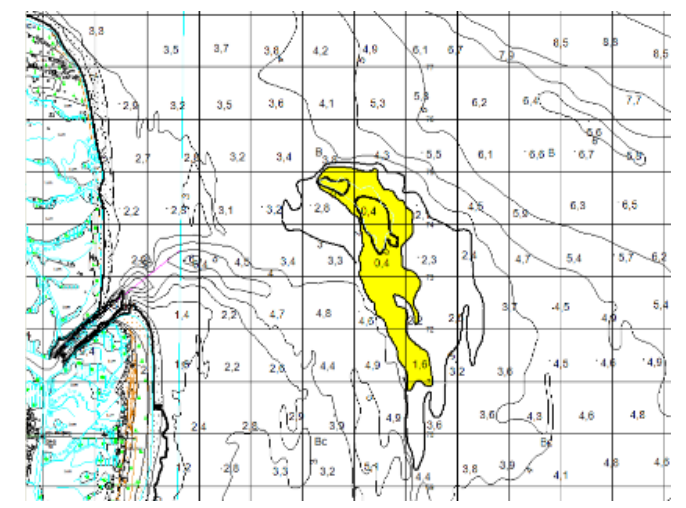

Hình $6 \mathrm{c}$. Cồn cát ngầm cửa sông gần nổi cao phía đông nam Cung Hầu [6].

Các cồn chắn cửa sông là sản phẩm của quá trình tái trầm tích do hoạt động của sóng và các dòng chảy ven bờ. Các thể cát có độ chọn lọc tốt $(\mathrm{So}<1,5)$, độ mài tròn từ trung bình đến tốt
(Ro>0,4) đã chứng minh cho môi trường thủy động lực có sóng mạnh và lặp lại lâu dài. 


\section{Tiền châu thổ và sườn châu thổ}

Tiền châu thổ và sườn châu thổ thay đổi từ độ sâu $0-25 \mathrm{~m}$ nước, phân bố thành một hình quạt bao quanh đường bờ hiện đại gồm hai nhóm tướng:

(1) Tướng bùn cát tiền châu thổ phân bố ở độ sâu 0-6m nước, địa hình bằng phẳng.

(2) Tường bùn sườn châu thổ phân bố ở sườn dốc châu thổ từ độ sâu 6-23m nước.

Tiến hóa hệ thống giòng cát và cồn cát

\section{Lịch sủ hình thành và phát triển cồn cát}

Trên cơ sở phân tích địa mạo, cổ địa lý, trình tự hình thành và số liệu định tuổi tuyệt đối, tập thể tác giả đã khôi phục lịch sử hình thành và tiến hóa các cồn cát diễn ra theo 4 giai đoạn sau đây (Hình 7):

Giai đoạn 1 : Tôn cao đáy biển nhờ dư thừa trầm tích. Giai đoạn này đánh dấu một quá trình vận chuyển và lắng đọng trầm tích trong điều kiện sông Mekong dư thừa trầm tích. Bờ biển được dịch chuyển ra phía ngoài và đáy biển được tôn cao khiến cho độ sâu dáy biển đạt tới ngưỡng của đới sóng đổ: $D=1 / 2 h$, trong đó: $D$ là độ sâu đáy biển, $h$ là độ cao sóng.

Giai đoạn 2: Hình thành cồn cát ngầm. Khi sóng từ ngoài khơi vào đến độ sâu đáy biển nhỏ hơn $1 / 2$ độ cao bước sóng, tốc độ truyền sóng ở đỉnh và ở đáy mặt sóng không đồng nhất (đỉnh sóng có tốc độ lan truyền nhanh hơn so với đáy do ma sát và độ nhám (bottom roughness) của đáy biển) con sóng bị biến dạng, chiều cao tăng lên và đổ về phía trước khiến cho trầm tích đáy biển bị xáo trộn, vật liệu cát lắng đọng. Dần dần "mầm" cát được vun cao thành cồn cát ngầm.

- Giai đoạn 3: Cồn cát ngầm nổi cao thành đảo chắn. Trong giai đoạn thời tiết bình thường, độ cao cồn ngầm chỉ đạt tới độ cao MNB trung bình của thủy triều. Khi có những cơn bão xuất hiện mực nước biển dâng cao từ $2-3 \mathrm{~m}$ so với mực nước biển bình thường. Lúc này sóng bão và dòng chảy ven bờ vun cao cồn cát ngầm đạt tới độ cao mực nước dâng do bão. Đến khi thời tiết trở lại bình thường, cồn cát ngầm trở thành cồn nổi cao trên mực nước biển từ 2-3m [7].

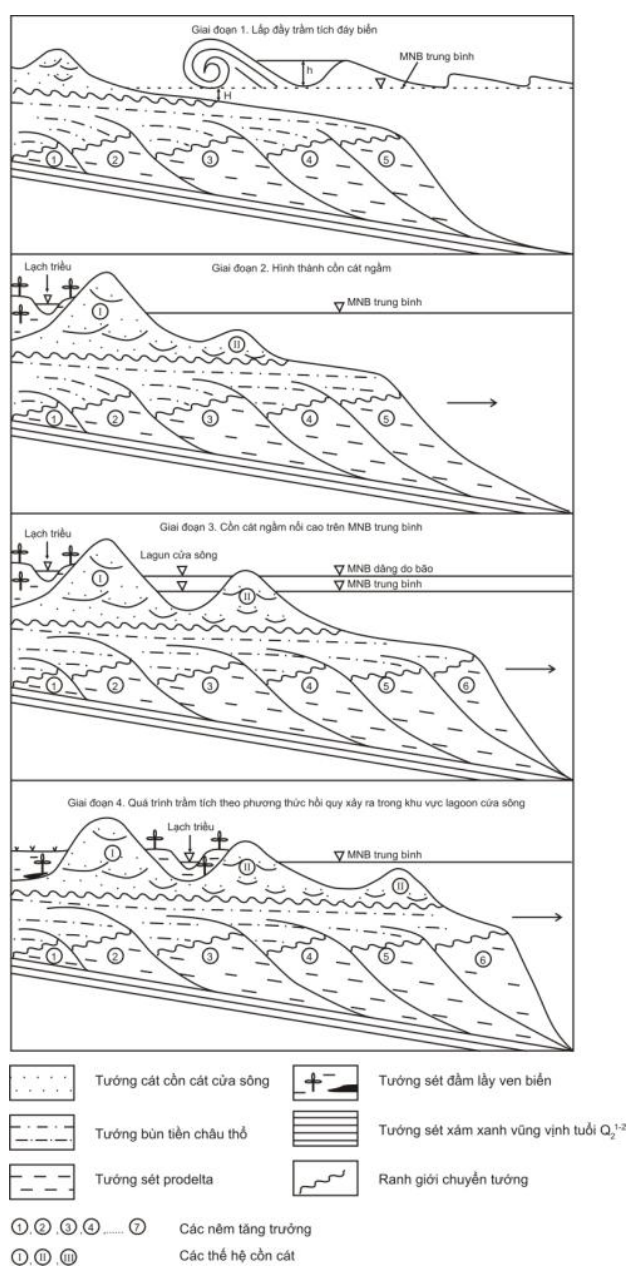

Hình 7. Cơ chế hình thành và lịch sử phát triển các cồn cát cửa sông khu vực sông Mekong.

- Giai đoạn 4: Quá trình trầm tích theo phương thức hồi quy xảy ra trong khu vực lagoon cửa sông. Trầm tích bùn bồi tụ từ ven rìa cồn trong ra và từ rìa cồn ngoài vào. Dần dần cồn cát được mở rộng còn cửa sông bị thu hẹp tạo thành hai lạch triều chảy ra biển (hình 8).

Lịch sử hình thành các thế hệ đường bò̀ cổ và tốc độ bồi tu của đồng bằng châu thổ sông Mekong

Trên cơ sở nghiên cứu tuổi tuyệt đối các thế hệ giồng cát trên đồng bằng châu thổ [8],[9] cho thấy châu thổ sông Mekong không phải tăng trưởng một cách liên tục về phía biển mà theo 5 đới bờ cổ được ghi nhận trên địa hình-địa mạo 
của đồng bằng châu thổ sông Mekong: đới bờ 5.000 năm, 2.500 năm, 1.000 năm, 500 năm và đường bờ hiện tại (Hình 8,9 ). Tại mỗi đới bờ Sông Tiền và Sông Hậu đã tạo ra các quạt châu thổ hay gọi là thùy châu thổ. Bốn thế hệ quạt châu thổ nối tiếp và phủ chồng lùi lên nhau tạo nên một mặt cắt địa chất trầm tích có ranh giới chéo từ đất liền ra biển. Các giồng cát có tuổi trẻ dần từ đất liền ra biển có ranh giới chéo từ dưới lên trên mặt. Tuy nhiên xét trong cấu trúc của mặt cắt thẳng đứng các đơn vị tướng (ĐBCT, TCT, Sườn châu thổ) thì có ranh giới chuyển tướng nằm ngang [10]. Mỗi đơn vị tướng của châu thổ đều có tuổi trẻ dần từ lục địa $\mathrm{ra}$ biển. Riêng nhóm tướng đồng bằng châu thổ có bề dày mỏng dần từ trong ra đến $0 \mathrm{~m}$ hải đồ.

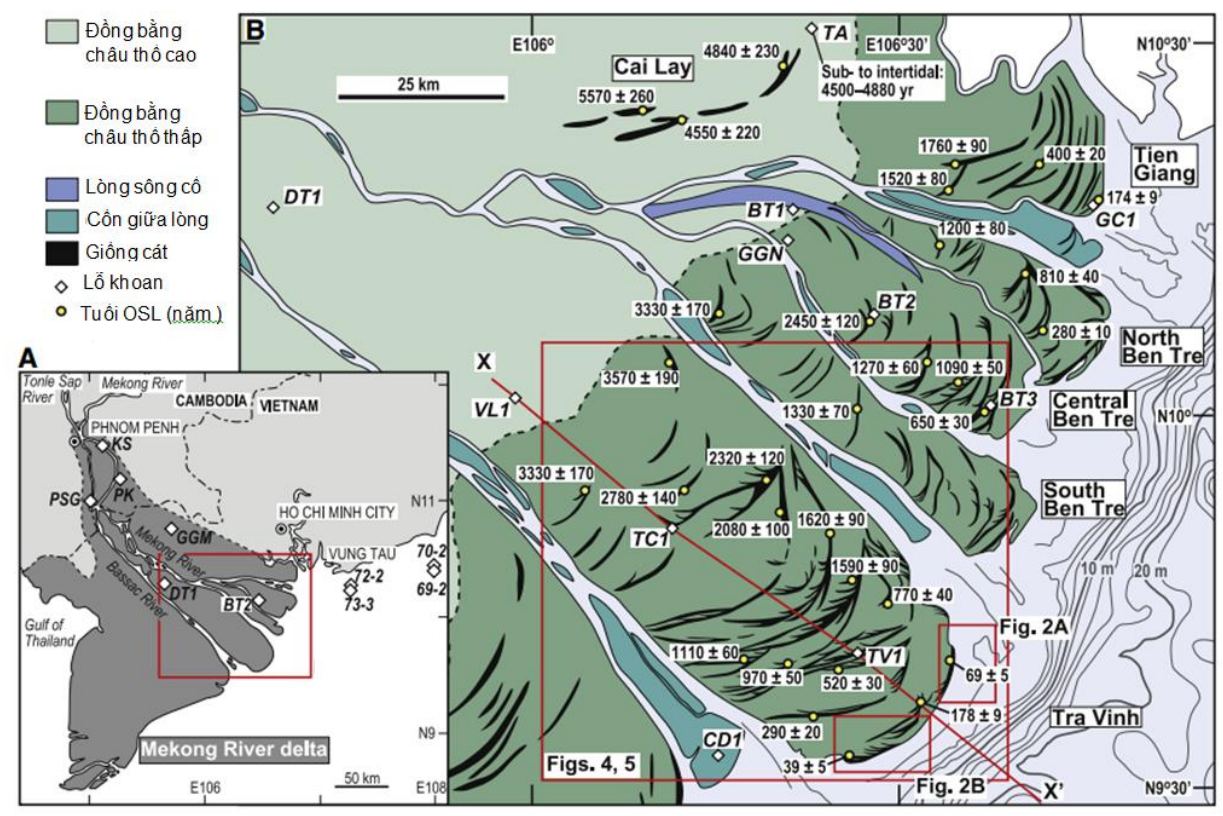

Hình 8. Sơ đồ các giồng cát và tuổi OSL của chúng theo Toru Tamura (2012) [1]

Bảng 2. Tiến hóa các giồng cát trong mối quan hệ với sự thay đổi mực nước biển

\begin{tabular}{|c|c|c|c|c|c|c|c|}
\hline $\begin{array}{l}\text { Đường bờ } \\
\text { cồ (năm) }\end{array}$ & $\begin{array}{l}\text { Tuổi giồng cát } \\
\text { (năm) }\end{array}$ & So & $\mathrm{Q}(\%)$ & Ro & $\mathrm{Li}$ & Mt & MNB \\
\hline Hiện tại & 0 & 1.25 & 79,0 & 0.75 & 0.01 & 1.22 & \\
\hline \multirow[t]{2}{*}{500} & $290 \pm 20$ & 1.27 & 76.8 & 0.76 & 0.02 & 1.18 & \\
\hline & $520 \pm 30$ & 1.29 & 16.5 & 0.77 & 0.03 & 1.63 & \\
\hline \multirow[t]{3}{*}{1000} & $970 \pm 50$ & 1.30 & 15.6 & 0.74 & 0.05 & 1.11 & \\
\hline & $1110 \pm 60$ & 1.33 & 70.5 & 0.75 & 0.07 & 1.04 & \\
\hline & $1320 \pm 70$ & 1.35 & 69.2 & 0.68 & 0.06 & 0.97 & \\
\hline \multirow[t]{3}{*}{2500} & $2450 \pm 120$ & 1.58 & 67.6 & 0.67 & 0.09 & 0.81 & \\
\hline & $2730 \pm 140$ & 1.65 & 68.1 & 0.63 & 0.11 & 0.74 & \\
\hline & $3330 \pm 170$ & 1.67 & 65.3 & 0.65 & 0.10 & 0.74 & \\
\hline \multirow[t]{2}{*}{5000} & $4840 \pm 230$ & 1.75 & 61.5 & 0.55 & 0.12 & 0.62 & \\
\hline & $5570 \pm 260$ & 1.90 & 55.2 & 0.51 & 0.15 & 0.52 & \\
\hline
\end{tabular}


Lịch sử hình thành năm thế hệ đường bờ cổ gắn liền với các giai đoạn dâng cao và hạ thấp mực nước biển, cụ thể:

- Đường bờ cổ 5.000 năm $\mathrm{BP}$. Đường bờ cổ 5.000 năm $\mathrm{BP}$ được xác định bằng phương pháp OSL từ các giồng cát ở khu vực Cai Lậy có tuổi $5.570 \pm 260,4.840 \pm 230,4.550 \pm 220$ năm $\mathrm{BP}$ (Hình 9a). Đường bờ biển này đánh dấu mực nước biển đâng cao cực đại $+5 \mathrm{~m}$ của pha biển tiến Flandrian (Holocen giữa) và dừng lại trong khoảng thời gian từ 6.000-5.000 năm $\mathrm{BP}$.

- Đường bờ cổ 2.500 năm $\mathrm{BP}$. Được đánh dấu bằng hệ thống các giồng cát có tuổi $3.330 \pm 170,3.570 \pm 190,2.780 \pm 140$ năm BP (Hình 9b), tương ứng với mực nước biển hạ thấp $+2,5 \mathrm{~m}$ và dừng lại trong khoảng thời gian từ 3.000-2.500 năm $\mathrm{BP}$.

- Đường bờ cổ 1.000 năm $\mathrm{BP}$, nằm cách xa đường bờ hiện đại $50 \mathrm{~km}$. Được dánh dấu bằng hệ thống các giồng cát có tuổi $1.110 \pm 60$, $1.090 \pm 60,970 \pm 50$ (Hình 9c), tương ứng với mực nước biển đã hạ sâu $-2 \mathrm{~m}$ nước so với mực nước biển hiện đại, dừng lại trong khoảng thời gian từ 1.500-1.000 năm.

- Đường bờ cổ 500 năm $\mathrm{BP}$, nằm cách đường bờ hiện đại $20 \mathrm{~km}$. Tương ứng với mực nước biển ấn định ở độ sâu $-1 \mathrm{~m}$ nước so với mực nước biển hiện đại và hệ thống giồng cát có tuổi $502 \pm 30,400 \pm 20,290 \pm 20$ (Hình 9d).
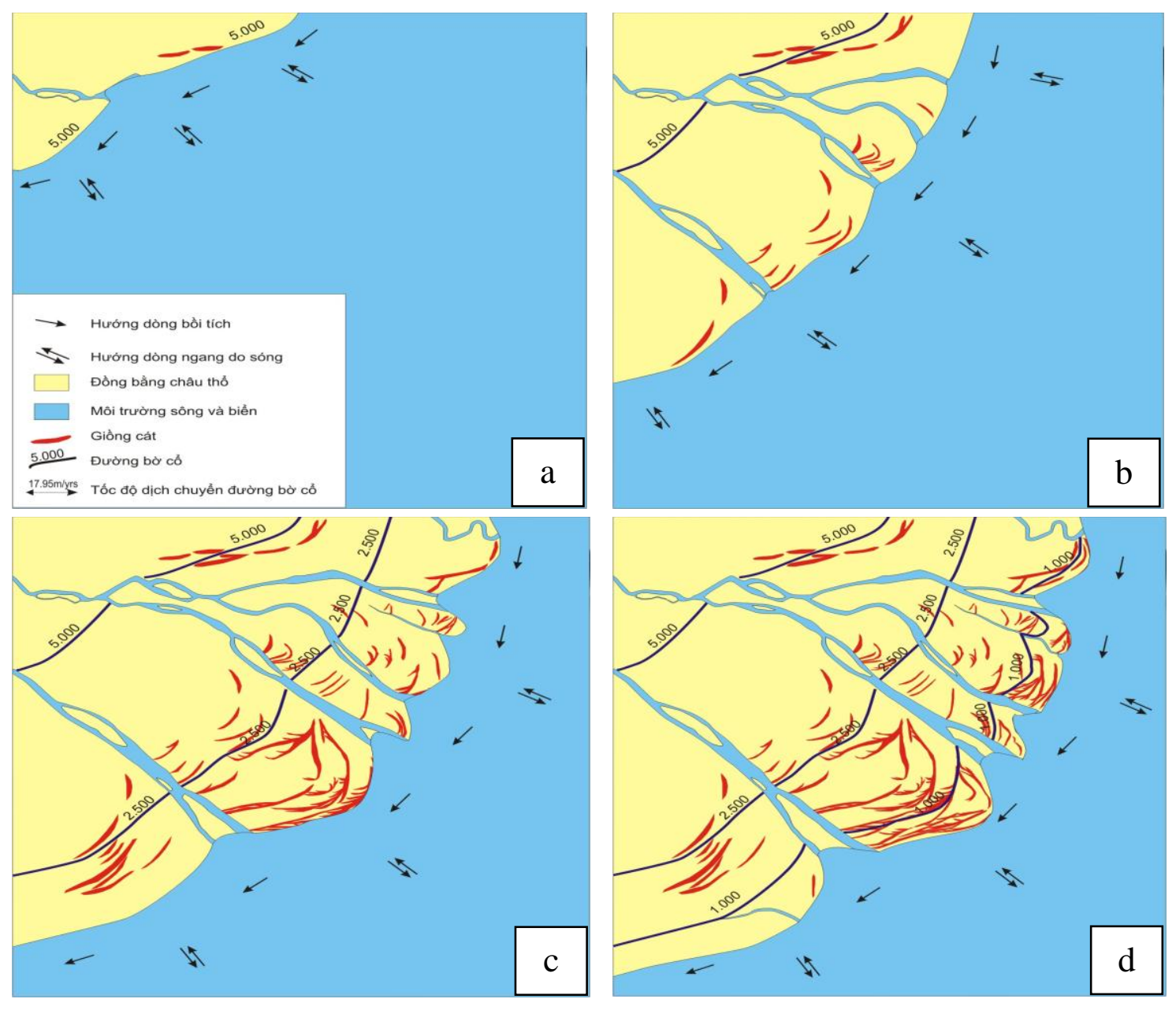


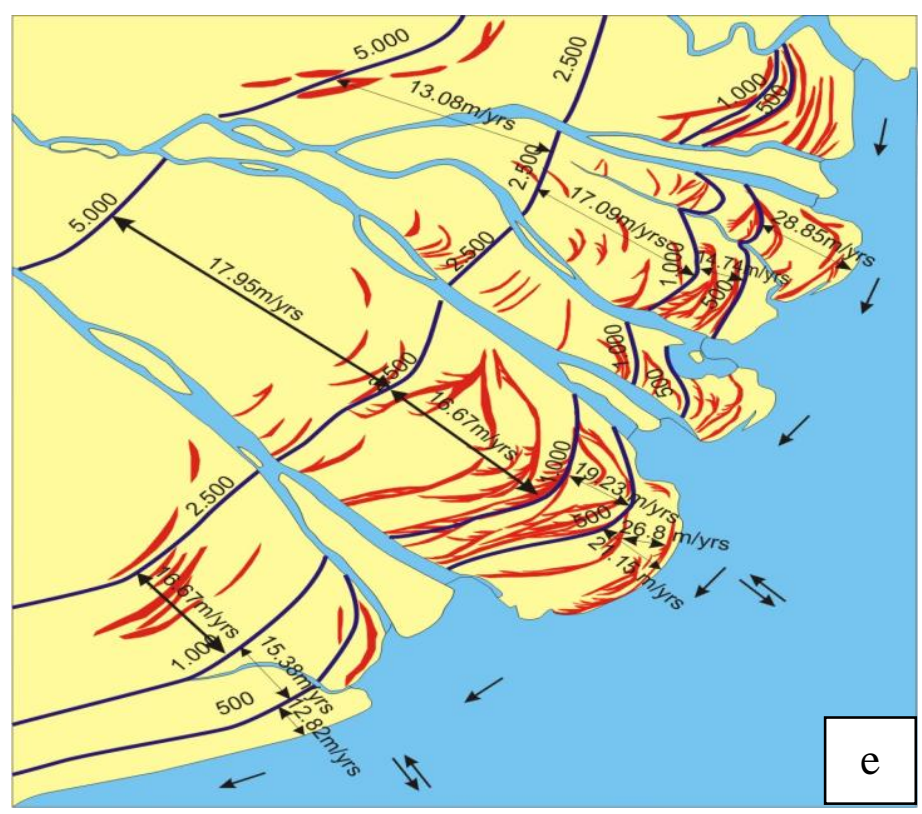

Hình 9. Các vị trí đường bờ cổ trên đồng bằng châu thổ sông Mekong.
a. Đường bờ 6.000-5.000 BP
$\mathrm{b}$. Đường bờ 3.000-2.500 $\mathrm{BP}$
c. Đường bờ 1.500-1.000 BP
$\mathrm{d}$. Đường bờ 1.000-500 BP
e. Đường bờ hiện tại

Tốc độ dịch chuyển của đường bờ về phía biển từ khoảng 5.000 năm đến nay được tính toán dựa trên công bố tuổi tuyết đối OSL của trầm tích các giồng cát phân bố trên vùng đồng bằng châu thổ [1] (Bảng 3). Kết quả tính toán cho thấy tốc độ dịch chuyển trung bình thay đổi từ $10,93 \mathrm{~m} / \mathrm{năm}$ (Tiền Giang) đến $24,27 \mathrm{~m} / \mathrm{năm}$ (Bắc Bến Tre). Khu vực Trà Vinh có tốc độ dịch chuyển ổn định nhất ở cả ba đới bắc, trung tâm và phía nam (từ 17,01-18,1m/năm). Trong đó tốc độ dịch chuyển ở đới phía bắc là ổn định nhất theo thời gian (khoảng $16-17 \mathrm{~m} /$ năm) trong khi tốc độ dịch chuyển ở phía đới trung tâm giảm dần và ở đới phía nam lại tăng dần theo thời gian. Khác với ở Trà Vinh, tốc độ dịch chuyển đường bờ ở khu vực Bến Tre lại rất khác nhau giữa ba đới: bắc, trung tâm và nam. Trong khi đới phía bắc có tốc độ dịch chuyển lớn nhất (trung bình $24,27 \mathrm{~m} /$ năm), đới phía nam có tốc độ dịch chuyển trung bình (trung bình $16,66 \mathrm{~m} / \mathrm{năm})$ thì đới trung tâm tốc dộ dịch chuyển đường bờ lại thấp nhất (trung bình chỉ đạt $11,02 \mathrm{~m} /$ năm).

Dựa trên 5 đường bờ được xác định trên Hình $9 \mathrm{e}$, tốc độ dịch chuyển các đường bờ cổ qua từng giai đoạn (5.000 năm tới 2.500 năm, 2.500 năm tới 1.000 năm, 1.000 năm tới 500 năm và $500 \mathrm{~m}$ tới bờ hiện tại) được tính toán thể hiện ở bảng 4 . Khu vực trung tâm châu thổ (Trà Vinh) là vị trí có tốc độ bồi tụ cao nhất ở giai đoạn từ 5.000 năm tới 2.500 năm và 1.000 năm tới 500 năm. Khu vực trung tâm rìa bắc châu thổ (Bến Tre) lại là khu vực có tốc độ bồi tụ cao nhất ở giai đoạn 2.500 năm tới 1.000 năm và giai đoạn 500 năm tới hiện tại, tuy nhiên đây cũng là khu vực có sự biến động lớn về tốc độ dịch chuyển đường bờ. Khu vực rìa nam châu thổ có tốc độc dịch chuyển đường bờ giảm dần qua các giai đoạn từ 2.500 năm tới 1.000 năm tới 500 năm và tới hiện tại. 
Bảng 3. Tốc độ dịch chuyển đường bờ về phía biển từ 5.000 năm tới nay tính theo tuổi của hệ thống giồng cát ven biển

\begin{tabular}{|c|c|c|c|c|}
\hline Tỉnh & Khu vực & $\begin{array}{l}\text { Tuồi } \\
\text { giồng cát } \\
\text { (năm BP) }\end{array}$ & $\begin{array}{l}\text { Khoảng } \\
\text { cách tới bờ } \\
\text { biển hiện tại } \\
(\mathrm{km})\end{array}$ & $\begin{array}{l}\text { Tốc độ } \\
\text { (m/năm) }\end{array}$ \\
\hline \multirow{5}{*}{$\begin{array}{l}\text { Tiền } \\
\text { Giang }\end{array}$} & & 4.840 & 52,89 & 10,93 \\
\hline & & 1.760 & 23,04 & 13,09 \\
\hline & & 400 & 12,01 & 30,03 \\
\hline & & 170 & 1,50 & 8,81 \\
\hline & & 1.200 & 29,12 & 24,27 \\
\hline \multirow{8}{*}{ Bến Tre } & \multirow[t]{3}{*}{ Bắc } & 800 & 16,33 & 20,41 \\
\hline & & 280 & 9,178 & 32,78 \\
\hline & & 2.450 & 26,99 & 11,02 \\
\hline & \multirow{3}{*}{$\begin{array}{l}\text { Trung } \\
\text { tâm }\end{array}$} & 1.270 & 16,55 & 13,03 \\
\hline & & 1.090 & 11,10 & 10,18 \\
\hline & & 650 & 5,07 & 7,79 \\
\hline & \multirow{2}{*}{ Nam } & 3.330 & 55,48 & 16,66 \\
\hline & & 1.370 & 30,36 & 22,16 \\
\hline \multirow{11}{*}{ Trà Vinh } & \multirow{5}{*}{ Bắc } & 3.570 & 60,73 & 17,01 \\
\hline & & 2.320 & 38,72 & 16,69 \\
\hline & & 1.620 & 26,13 & 16,13 \\
\hline & & 1.590 & 20,03 & 12,60 \\
\hline & & 770 & 13,04 & 16,94 \\
\hline & \multirow{3}{*}{$\begin{array}{l}\text { Trung } \\
\text { tâm }\end{array}$} & 2.780 & 50,33 & 18,10 \\
\hline & & 520 & 14,98 & 28,81 \\
\hline & & 180 & 2,25 & 12,51 \\
\hline & \multirow{3}{*}{ Nam } & 3.330 & 57,69 & 17,32 \\
\hline & & 1.110 & 23,28 & 20,97 \\
\hline & & 290 & 10,00 & 34,48 \\
\hline
\end{tabular}

Bảng 4. Tốc độ dịch chuyển các đường bờ cổ từ 5000 năm đến nay

\begin{tabular}{|c|c|c|c|c|c|c|c|}
\hline \multirow[t]{2}{*}{$\begin{array}{l}\text { Đường } \\
\text { bờ (năm) }\end{array}$} & \multirow{2}{*}{$\begin{array}{l}\text { Thời gian } \\
\text { thành tạo } \\
\text { (năm) }\end{array}$} & \multicolumn{2}{|c|}{$\begin{array}{l}\text { Khu vực Bến Tre } \\
\text { (Rìa bắc châu thổ) }\end{array}$} & \multicolumn{2}{|c|}{$\begin{array}{l}\text { Khu vực Trà Vinh } \\
\text { (Trung tâm châu thổ) }\end{array}$} & \multicolumn{2}{|c|}{$\begin{array}{l}\text { Khu vực Sóc Trăng } \\
\text { (Rìa nam châu thổ) }\end{array}$} \\
\hline & & $\begin{array}{l}\text { Khoảng } \\
\text { cách }(\mathrm{km})\end{array}$ & $\begin{array}{l}\text { Vận tốc } \\
\text { (m/năm) }\end{array}$ & $\begin{array}{l}\text { Khoảng } \\
\text { cách }(\mathrm{km})\end{array}$ & $\begin{array}{l}\text { Vận tốc } \\
\text { (m/năm) }\end{array}$ & $\begin{array}{l}\text { Khoảng } \\
\text { cách }(\mathrm{km})\end{array}$ & $\begin{array}{l}\text { Vận tốc } \\
\text { (m/năm) }\end{array}$ \\
\hline \multicolumn{8}{|l|}{5.000} \\
\hline & 2.500 & 32,692 & 13,08 & 44,872 & 17,95 & & \\
\hline 2.500 & 1.500 & 25,641 & 17,09 & 25,000 & 16,67 & 25,000 & 16,67 \\
\hline 1.000 & & & & & & & \\
\hline 500 & 500 & 7,372 & 14,74 & 9,615 & 19,23 & 7,692 & 15,38 \\
\hline Hiện tại & 500 & 14,423 & 28,85 & 10,577 & 21,15 & 6,41 & 12,82 \\
\hline
\end{tabular}




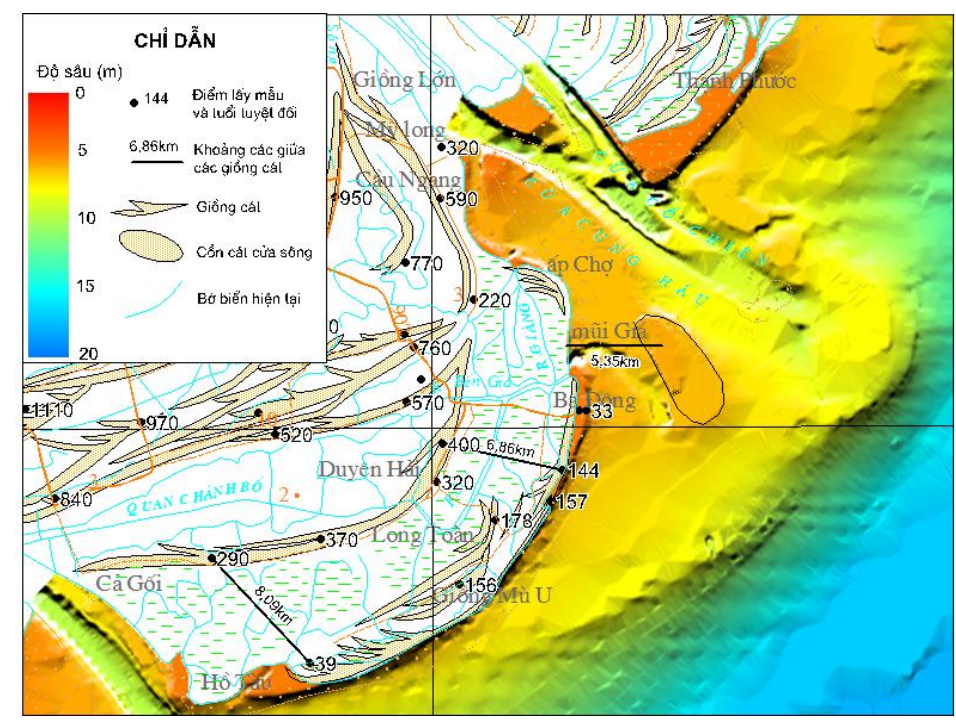

Hình 10. Hệ thống giồng cát 400 năm và 144 năm cách ngày nay vùng đồng bằng ven biển Trà Vinh.

Dư báo xu thế biến đổi các thế hệ cồn cát châu thổ sông Mekong

Trong điều kiện nguồn trầm tích không thay đổi so với giai đoạn trước đắp đập thủy điện và mực nước biển tăng với tốc độ hiện tại (khoảng $2 \mathrm{~mm} / \mathrm{năm})$ [11] thì đường bờ biển châu thổ từ Cửa Tiểu đến Cửa Trần Đề vẫn tiến ra biển theo chu kỳ theo mô hình tích tụ trầm tích hướng tâm (Hình 10). Trường hợp cụ thể được dự báo cho vùng bờ biển Trà Vinh. Dựa trên kết quả phân tích tuổi tuyệt đối (Hình 7 , Hình 10 ), tốc độ bồi tụ trung bình từ khoảng 400 năm đến 144 năm cách ngày nay ở vùng đồng bằng ven biển phía bắc Trà Vinh trung bình là $26,8 \mathrm{~m} /$ năm. Với tốc độ này thì trong khoảng 200 năm nữa đường bờ biển sẽ ở vị trí cồn cát trước cửa sông Cung Hầu cách bờ $5.355 \mathrm{~m}$. Với tốc độ tích tụ theo chiều thẳng đứng của các giồng cát được xác định cũng từ kết quả phân tích tuổi tuyệt đối là $24,24 \mathrm{~mm} / \mathrm{năm}$ thì trong khoảng 200 năm tới cồn cát trước cửa sông Cung Hầu sẽ cao khoảng 4,85m $(24,24 \mathrm{~mm} / \mathrm{năm}$ x 200 năm)/1000 tương tự độ cao của giồng cát ven biển hiện tại. Sự phù hợp giữa tốc độ tích tụ thẳng đứng và tốc độ dịch chuyển ngang của đường bờ về phía biển cho thấy kết quả dự đoán có độ tin cậy khá cao.

\section{Kết luận}

Dựa trên những kết quả mới thu được đã cho phép tập thể tác giả rút ra một số kết luận sau:

Trên đồng bằng châu thổ sông Mekong ghi nhận 5 thế hệ cồn cát với tuổi tương ứng 5.000 năm, 2.500 năm, 1.000 năm, 500 năm và thế hệ cồn cát tại đường bờ hiện đại. Càng về phía biển tuổi các cồn cát càng trẻ. Hệ thống cồn cát đóng vai trò là các mốc đánh dấu quá trình phát triển của châu thổ về phía biển từ hơn 5.000 năm trở lại đây. Trong khoảng thời gian này, đồng bằng châu thổ tăng trưởng không liên tục theo thời gian mà theo các chu kỳ hình thành cồn cát với khoảng cách trung bình $5 \mathrm{~km}$ và thời gian thành tạo từ 200-250 năm đến 450-500 năm /1 thế hệ giồng.

Mỗi chu kỳ của cồn cát cửa sông trải qua 4 giai đoạn: (1) Giai đoạn tôn cao địa hình đáy biển; (2) giai đoạn hình thành cồn cát ngầm; (3) giai đoạn cồn cát ngầm nổi cao trên MNB trung 
bình; (4) giai đoạn bồi tụ trầm tích hồi quy tạo đồng bằng châu thổ thấp và lạch triều.

Một thế hệ giồng cát đặc trưng bởi tổ hợp cộng sinh tướng cát giồng cát và tướng bột sét bãi bồi châu thổ. Hiện nay đáy biển ven bờ thuộc tiền châu thổ đang hình thành một hệ thống cồn cát ngầm về phía nam tây nam các cửa sông. Tính toán dựa trên tuổi các giồng cát cổ cho phép dự báo trong khoảng 200 năm tới cồn cát ngầm sẽ nổi cao như cồn cát ở đường bờ hiện đại với độ cao khoảng $5 \mathrm{~m}$.

\section{Lời cảm ơn}

Nghiên cứu này được tài trợ bởi Trường Đại học Khoa học Tự nhiên trong đề tài mã số TN.17.14.

\section{Tài liệu tham khảo}

[1] Tamura, T., Yoshiki Saito, Mark D. Bateman, V. Lap Nguyen, T.K. Oanh Ta, Dan Matsumoto, Luminescence dating of beach ridges for characterizing multi-decadal to centennial deltaic shoreline changes during Late Holocene, Mekong River delta, Marine Geology 326-328, 2012, 140-153.

[2] Tamura, T., Saito, Y., Nguyen, V.L., Ta, T.K.O., Le, M.D., Bateman, M.D., Matsumoto, D., Yamashita, S., Origin and evolution of interdistributary delta plains; insights from Mekong River delta. Geology 40, 2012, 303-306.

[3] Đinh Xuân Thành, Nghiên cứu lịch sử tiến hóa châu thổ ngầm sông Mekong trong Holocen phục vư phát triển bền vững. Đề tài khoa học công nghệ cấp nhà nước, mã số KC09.13/11-15, 2015.
[4] Nguyễn Địch Dỹ, Nghiên cứu biến động cửa sông và môi trường trầm tích Holocen - hiện đại vùng ven biển châu thổ Sông Cửu Lòng, phục vụ phát triển bền vững kinh tế - xã hội. Đề tài khoa học công nghệ cấp Nhà nước, mã số KC09.06/0610, 2010.

[5] Anthony EJ, Brunier G, Besset M, Goichot M, Dussouillez P, Nguyen VL, Linking rapid erosion of the Mekong River delta to human activities, Scientific Reports 5, 14745, 2015.

[6] Trung tâm Trắc địa Bản đồ biển là Bản đồ địa hình đáy biển. Bản đồ địa hình đáy biển tỷ lệ 1/50.000 thuộc vùng lãnh hải.

[7] Erban, L.E., Steven M Gorelick, Howard A Zebker, Groundwater extraction, land subsidence, and sea-level rise in the Mekong Delta, Vietnam, Environmental Research Letters. 9, 084010, 2014, (6 pp).

[8] Kondolf G.M, Annandale. G., Rubin Z. K., Sediment starvation from dams in the lower Mekong River Basin: Magnitude of the effect and potential mitigation opportunities, E-proceedings of the 36th IAHR World Congress 28 June-3 July, 2015, The Hague, the Netherlands.

[9] Kondolf G. M., Rubin Z. K., and Minear J. T., Dams on the Mekong: Cumulative sediment starvation, Water Resources Research, 50:1-12, 2014.

[10] Tran Nghi, Nguyen Dich Dy, Doan Dinh Lam, Dinh Xuan Thanh, Nguyen Dinh Thai, Tran Thi Thanh Nhan, Giap Thi Kim Chi, Nguyen Thi Huyen Trang, Evolution of holocene depositional environments in the coastal area from the Tien river to the Hau river mouths. VNU Journal of Science, Earth Sciences. Vol 26, No.4 (E.S), 2010, Page: 185-201.

[11] Bộ Tài nguyên và Môi trường, Kịch bản biến đổi khí hậu, nước biển dâng cho Việt Nam, NXB Tài nguyên-Môi trường và Bản đồ Việt Nam, 2012. 


\title{
Sandy Ridges System Evolution of Mekong Delta, Southern Vietnam and Its Role in Contructing History of Mekong Delta in Late Holocene
}

\author{
Nguyen Thi Huyen Trang, Tran Nghi, Dinh Xuan Thanh, \\ Tran Thi Thanh Nhan, Nguyen Thi Tuyen
}

VNU University of science, 334 Nguyen Trai, Hanoi, Vietnam

\begin{abstract}
Abtract: Sandy ridges sytem in the Mekong delta take an importance role in making progading process of delta toward the sea from 5,000 years BP. The generations of sandy ridges are the imprints of the ancient shoreline generations. There are five generations of sandy ridges with the age of 5,000 years, 2,500 years, 1,000 years, 500 years and finally the present sandy ridge which are forming at the modern shoreline. The nearer to the sea is younger. Currently, a series of delta front bars is forming to the south and southeast of river mouths. The delta front bar is predicted to reach $5 \mathrm{~m}$ high in the next 200 years and connect to the mainland as the present sandy ridge, based on obsolute age data of the ancient sandy ridges. At that time, the Mekong delta will enter a period of intense accretion and the current delta front will turn into a lower delta plain. However, human activities such as hydropower dam construction on the mainstream of the Mekong river and sand exploitation in river channel are causing seriously decrease sediment discharge.
\end{abstract}

Keywords: Sandy ridge, delta front bar, Mekong delta, ancient shoreline. 